\title{
Spatial Distribution of Heavy Metals and the Environmental Quality of Soil in the Northern Plateau of Spain by Geostatistical Methods
}

\author{
Fernando Santos-Francés ${ }^{1}$, Antonio Martínez-Graña ${ }^{2, *}$, Carmelo Ávila Zarza ${ }^{3}$, \\ Antonio García Sánchez ${ }^{4}$ and Pilar Alonso Rojo ${ }^{1}$ \\ 1 Department of Soil Sciences, Faculty of Agricultural \& Environmental Sciences, University of Salamanca, \\ Avenue Filiberto Villalobos, 119, 37007 Salamanca, Spain; fsantos@usal.es (F.S.-F.); palrojo@usal.es (P.A.R.) \\ 2 Department of Geology, Faculty of Sciences, University of Salamanca, Plaza de la Merced s/n., \\ 37008 Salamanca, Spain \\ 3 Department of Statistics, Faculty of Agricultural \& Environmental Sciences, University of Salamanca, \\ Avenue Filiberto Villalobos, 119, 37007 Salamanca, Spain; caaz@usal.es \\ 4 Department of Environmental Geochemistry, Institute of Natural Resources and \\ Agrobiology_IRNASA (C.S.I.C.), Calle Cordel de Merinas 40, 37008 Salamanca, Spain; \\ antonio.gsanchez@irnasa.csic.es \\ * Correspondence: amgranna@usal.es; Tel.: +34-923-294-400-4496
}

Academic Editors: Prysor Williams and Davey Jones

Received: 8 April 2017; Accepted: 25 May 2017; Published: 26 May 2017

\begin{abstract}
The environmental quality of soil in the central part of the Northern Plateau of Spain has been analyzed by studying the heavy metal content of 166 samples belonging to the horizons A, B and C of 89 soil profiles. The analysis to assess the environmental risk of heavy metals in the soil was carried out by means of the spatial distribution of nine heavy metals and the use of several pollution indices. The results showed that the concentration values of heavy metals $(\bar{x} \pm S)$ in the superficial soil horizons were the following: With a total of $6.71 \pm 3.51 \mathrm{mg} \cdot \mathrm{kg}^{-1}$, the contents of $\mathrm{Cd}$ is $0.08 \pm 0.06 \mathrm{mg} \cdot \mathrm{kg}^{-1}, \mathrm{Co}$ is $6.49 \pm 3.21 \mathrm{mg} \cdot \mathrm{kg}^{-1}, \mathrm{Cu}$ is $17.19 \pm 10.69 \mathrm{mg} \cdot \mathrm{kg}^{-1}$, $\mathrm{Cr}$ is $18.68 \pm 12.28 \mathrm{mg} \cdot \mathrm{kg}^{-1}, \mathrm{Hg}$ is $0.083 \pm 0.063 \mathrm{mg} \cdot \mathrm{kg}^{-1}$, Ni is $12.05 \pm 6.76 \mathrm{mg} \cdot \mathrm{kg}^{-1}, \mathrm{~Pb}$ is $14.10 \pm 11.32 \mathrm{mg} \cdot \mathrm{kg}^{-1}$ and $\mathrm{Zn}$ is $35.31 \pm 14.63 \mathrm{mg} \cdot \mathrm{kg}^{-1}$. These nine metals exceed the values of the natural geological background level of Tertiary period sediments and rocks that form part of the Northern Plateau in Spain. Nemerow and Potential Ecological Risk indices were calculated, with the "improved" Nemerow index allowing pollution within the soil superficial horizons to be determined. The data obtained indicated that the majority of the soil (54.61\%) showed low to moderate contamination, $22.31 \%$ showed moderate contamination and $21.54 \%$ of the samples were not contaminated. If we consider the Potential of Ecological Risk Index (RI), the largest percentage of soil samples showed low $(70.79 \%)$ to moderate $(25.38 \%)$ ecological risk of potential contamination, where the rest of the soil presented a considerable risk of contamination. The nine trace elements were divided into three principal components: $\mathrm{PC}_{1}(\mathrm{Cu}, \mathrm{Cr}, \mathrm{Ni}, \mathrm{Co}$ and $\mathrm{Zn}), \mathrm{PC}_{2}$ (As and $\mathrm{Hg}$ ) and $\mathrm{PC}_{3}(\mathrm{Cd})$. All metals accumulated in the soil came from parent rock, agricultural practices and the run-off of residual waters towards rivers and streams caused by industrial development and an increase in population density. Finally, cartography of the spatial distribution of the heavy metal contents in the soil of the Northern Plateau of Spain was generated using Kriging interpolation methods. Furthermore, the total heavy metal contents in three soil orders present in the area, namely Entisols, Inceptisols, and Alfisols, were analyzed. Other soil parameters, such as the organic matter content, $\mathrm{pH}$, clay content and cation exchange capacity, was measured to determine their influence on and correlation with the heavy metal contents.
\end{abstract}

Keywords: soil; heavy metals; spatial distribution; environmental quality; Kriging; principal component analysis; Northern Plateau of Spain 


\section{Introduction}

Toxic heavy metals present in soil, such as $\mathrm{Cd}, \mathrm{Cu}, \mathrm{Pb}, \mathrm{Zn}, \mathrm{Ni}, \mathrm{Cr}$, and As, potentially affect the environment, because they are durable and non-biodegradable. The accumulation of toxic metals has an impact on natural ecosystems and can present a threat to humans through the food chain, owing to their bioaccumulation in food [1-4].

The natural concentrations of trace elements in soil play a key role in controlling the impact caused by humans and in the level of soil quality of an area [5-7]. Studies of soil contaminated by heavy metals have identified areas with a high risk of pollution through the analysis of atypical local spatial values $[8,9]$. The criteria and methods are diverse. However, spatial distribution analysis, localization of the sources of contamination and the assessment of soil quality are of particular interest $[10,11]$. The accumulation of heavy metals in soil is generally influenced by many environmental variables, including the parent rock and properties of the soil [12-14], as well as human activities, such as industrial production, traffic and agriculture. Extensive areas of land can be polluted by heavy metals released from waste incineration, industrial residual waters in addition to the application of fertilizers, pesticides and sewage sludge that contain heavy metals [15-17]. When different sources of contamination are present and their products are dispersed, the spatial variability of the heavy metal concentrations allows possible sources of contamination to be identified and the remediation strategies to be proposed. Independent of origin, the accumulation of heavy metals can damage soil quality and the efficiency of agricultural products, which can have to a negative impact on human health and ecosystems [18].

The assessment of environmental quality, based on the heavy metal contents in soil, involves the use of different pollution indices: the geoaccumulation index, the pollution load index, the potential of ecological risk index, the Nemerow index (Supplementary Materials) and so on. The geostatistical multivariate analysis implemented using geographic information systems (GIS) allows for more meaningful and accurate information. In soil pollution studies, the economic cost in addition to sampling and soil analysis should be taken into account, since dense and repetitive sampling is usually not very practical. With the aim to avoid these types of problems, the creation of maps representing the spatial distribution of contamination uses methods of spatial interpolation. The geostatistical method "Kriging" is currently used successfully to describe and predict the spatial variability of certain soil parameters and to predict values of non-sampled areas [19-28]. With the traditional statistical method, it is necessary for the data to be subjected to a series of assumptions: independent observations, wide and repeated sampling, etc.

Over the last decades, the research on the environmental geochemistry of heavy metals, owing to their toxicity and durability in the environment, has greatly advanced [29-31]. Recently, the analysis of principal components has been used in many fields to study soil, including pollution due to heavy metals. This is because this type of analysis shows the existing relationships between heavy metals in different spatial dimensions and determines the relative importance of each metal [32-35].

The presence of values that exceed the background threshold level of a given geological area is the traditional method used to characterize the degree of soil pollution [36]. High concentration levels of some heavy metals may occur through natural contamination (minerology and the chemical composition of the parent rock) or through anthropic pollution (agricultural land use, discharge of residual waters originating from industrial and urban areas towards rivers and streams, etc.).

The aim of the present work was to: quantify the environmental quality of the soil of the Northern Plateau of Spain by analyzing its heavy metal contents; assess the environmental risk of heavy metals by calculating various pollution indices and by analyzing their spatial and vertical distribution (within deep layers and throughout the entire soil profile); determine the correlation between the heavy metal contents and some soil parameters, such as the organic matter content, $\mathrm{pH}$, clay content and cation exchange capacity; and calculate the average content of heavy metals, according to the type of parent rock and land use. 


\section{Materials and Methods}

\subsection{Study Area}

The Northern Plateau, an area that forms part of the Spanish Central Plateau, is located to the north of the Central System and includes most of the autonomous regions of Castile and Leon. The study area, located within the Northern Plateau, occupies approximately $25,050 \mathrm{~km}^{2}$, which includes the whole area of the province of Valladolid and most of Palencia and Burgos. This area has a Mediterranean climate with cold and rainy winters in addition to hot and dry summers. The average annual rainfall is between 400 and $550 \mathrm{~mm}$, while the average annual temperature is between $11^{\circ} \mathrm{C}$ and $12.5^{\circ} \mathrm{C}$. The annual precipitation is less than the amount of potential evapotranspiration, which is between 660 and $730 \mathrm{~mm}$, and occurs mainly between November and February.

From a geological view point, this area belongs to the great Cenozoic depression of the Duero Basin, caused by the collapse of the Hercynian base and filled up throughout the entire Tertiary period with sediments originating from the continent with a tabular-horizontal arrangement. This basin is surrounded by mountains (Figure 1) [37].

In each lithological unit, an inventory of the most representative types of soil was conducted, with the profiles described and classified, according to the U.S. soil taxonomy $[38,39]$. The geographical distribution of the soil originating from the Duero basin is greatly influenced by the following shape-forming factors: lithology, relief and period or age of the geomorphological surfaces (Figure 1).

(a) Calcareous wastelands: this unit is comprised of the Late Miocene limestones that form a flat surface or a calcareous platform characteristic of wastelands, depending on their specific horizon. The physiographical features show a predominance of little-developed and dense soil (Xerorthents) as well as moderately thick soil (Rhodoxeralf and Haploxeralf).

(b) Gypsiferous loam slopes: a unit comprised mainly of soft materials (white and grey loams as well as small amounts of clays and gypsum) from the Late Miocene period. The soil comprising these hills and slopes has a clay-like texture, are highly chalky, and exhibit different degrees of erosion. These are related directly to the gradient of the slope, ranging from Haploxerepts to Xerorthents.

(c) Countryside or undulating plains: a unit shaped by detrital material and comprised of alternating sandstones and silty clays. This is slightly chalky and from the Miocene period (the so-called Tierra de Campos facies). The most characteristic soil on top of this type of lithology has been classified as Haploxerepts.

(d) Fluvial terraces: these terraces represent the remains of ancient riverbeds (Pleistocene), tiered to different heights. These run parallel and in the longitudinal direction along the course of the most abundant rivers (Duero, Pisuerga, Cea, and so on) and are comprised of generally well-cemented conglomerate deposits of quartzite, quartz and limestone in most of the ancient riverbeds. The lower or more modern riverbeds are comprised of gravel with sandy intercalations. The soil situated above this type of lithology has been classified as Palexeralfs and Haploxeralfs [40].

(e) Flood plains or water meadows of large rivers: these sediments are generally made up of silts, sand and loose gravel. The most characteristic soil of this unit has been classified as Calcixerepts and Xerofluvents.

(f) Wind sands: throughout the entire Quaternary period (Pleistocene-Holocene), wind gave rise to various erosional and sedimentation processes, creating loose arkose deposits with round grains. In some cases, these form dunes $15 \mathrm{~m}$ in depth, although these do not reach even one meter in other places. The sandy areas are usually alluvial deposits from rivers and sands from the Utrillas facies (Cretaceous), belonging to the Mesozoic period of the Iberian mountain range. This area is covered by white loose sands, forming soil classified as Xeropsamments. 


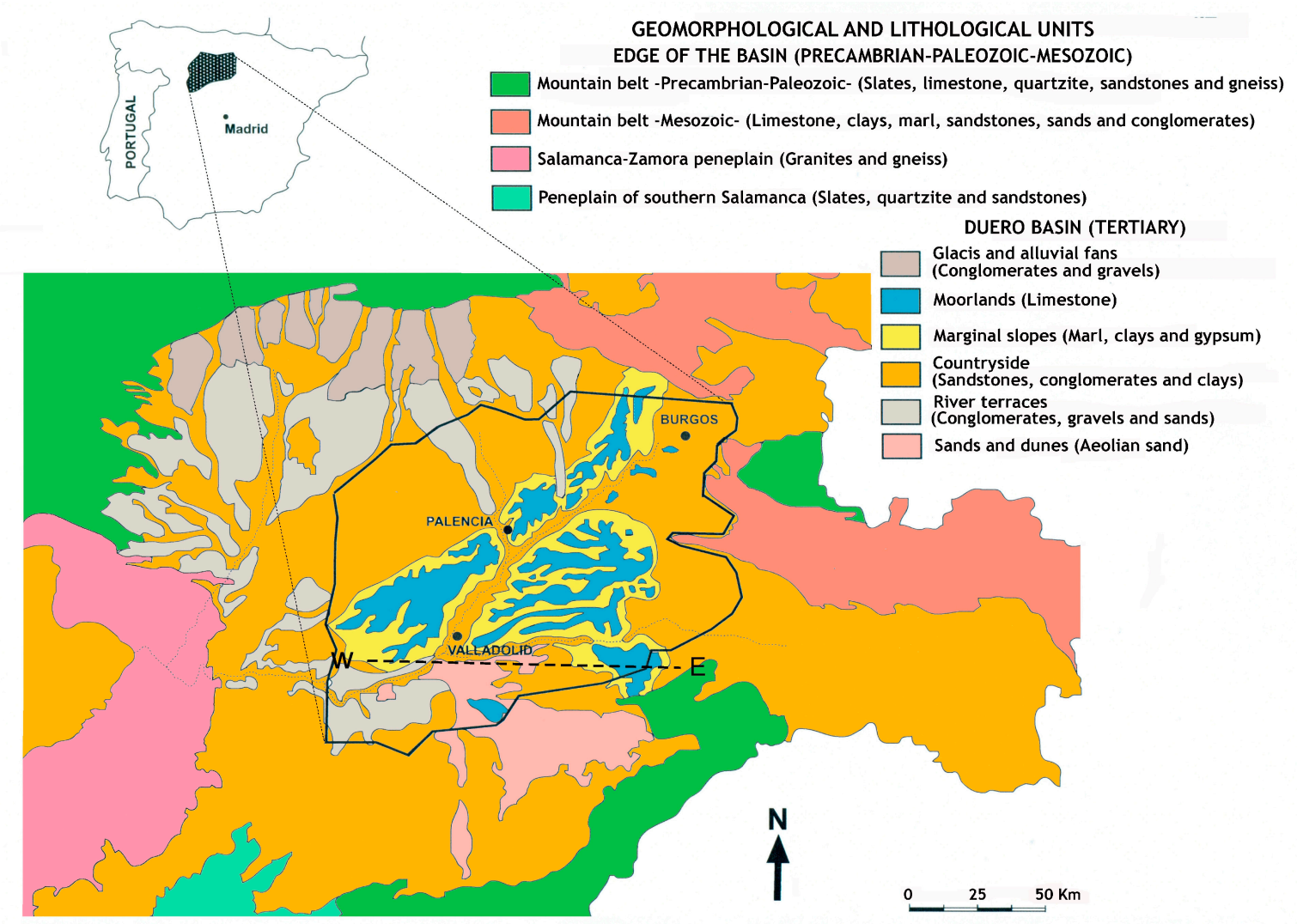

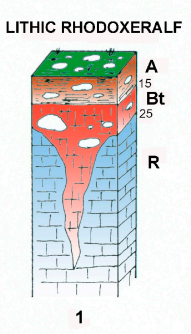
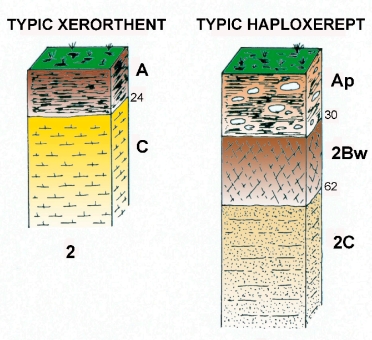

3

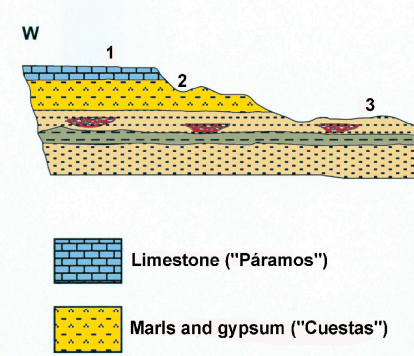

Figure 1. Geomorphological and lithological units of the Northern Plateau (Spain), location of study area (top) as well as the scheme that relates lithology, geomorphology and soil (bottom).

\subsection{Soil Samples}

The soil sampling sites were chosen, based on the different lithological units. In each site, individual samples were randomly taken for each of the horizons (A, B and C). In each horizon, five were collected and mixed to give homogeneity, obtaining a total of $1 \mathrm{~kg}$ of soil. This was subsequently dried at room temperature and then passed through a $2 \mathrm{~mm}$ sieve. In each site, individual samples are 
collected for each of the horizons (A, B and C). In each horizon, five sub-samples are collected and mixed to give homogeneity, obtaining a total sample of $1 \mathrm{~kg}$. The number of samples was 166 in total, which belongs to the soil profiles from the horizons A, B and C. Considering the five sub-samples of each horizons, the total number of collected samples is 830 . The physical and chemical properties were determined using the traditional soil analysis methods [41]: organic matter by oxidation with potassium dichromate, granulometric analysis using the Robinson pipette method, $\mathrm{pH}$ (water 1:1) and cation exchange capacity -CEC- using the ammonium acetate method (Table 1).

Table 1. Statistical summary of soil orders: mean $(\bar{x})$ and range $(\mathrm{R})$.

\begin{tabular}{cccccc}
\hline \multicolumn{1}{c}{ Soil Order } & & \% Clay & pH-H $\mathbf{2}_{\mathbf{2}} \mathbf{O}$ & \% Organic Matter & CEC cmol/kg \\
\hline Entisols & $\bar{x}$ & 27.8 & 7.45 & 1.3 & 14.2 \\
& $\mathrm{R}$ & $0.6-45.9$ & $7.0-7.7$ & $0.1-2.98$ & $0.6-31.0$ \\
\hline \multirow{2}{*}{ Inceptisols } & $\bar{x}$ & 21.4 & 7.01 & 0.6 & 14.2 \\
& $\mathrm{R}$ & $4.1-41.0$ & $5.8-8.2$ & $0.07-1.41$ & $1.9-31.4$ \\
\hline \multirow{2}{*}{ Alfisols } & $\bar{x}$ & 27.1 & 7.1 & 0.96 & 16.0 \\
& $\mathrm{R}$ & $1.5-62.1$ & $4.9-8.1$ & $0.16-2.55$ & $0.7-37.5$ \\
\hline
\end{tabular}

The total contents of heavy metals in soil have been analyzed according to the procedure recommended by the European Union ISO standard 11466. Extraction was performed with a mixture of nitric acid and hydrochloric acid in a microwave oven, with determination by ICP-MS model Elan 6000 of Perkin-Elmer. The analysis was carried out by the Chemical Analysis Service of the University of Salamanca through the digestion of the samples in a microwave oven (Millestone mod. Ethos Plus Microwave Lastation), using the standard method, USEPA method 3052. For the calibration of the equipment, standard solutions (panreac) of $1000 \mathrm{mg} / \mathrm{L}$ of all the metals analyzed were used, which were calibrated from 10 to $100 \mathrm{ppb}$. The data of the relative standard deviation (RSD) have all been less than $3 \%$ for all elements analyzed.

In addition, to check the quality of the analysis, blind duplicates were analyzed. The quality control of the data showing detection limits, accuracy and precision. For the elements: $\mathrm{As}, \mathrm{Cd}, \mathrm{Co}, \mathrm{Cu}$, $\mathrm{Cr}, \mathrm{Hg}, \mathrm{Ni}, \mathrm{Pb}$ and $\mathrm{Zn}$, the detection limit are: $0.1,0.01,0.1,0.01,0.5,5,0.1,0.01$, and 0.1 respectively, the accuracy is $2.3 \%, 0.6 \%, 1.4 \%, 3.2 \%, 7.6 \%, 1.3 \%, 1.7 \%, 1.4 \%$ and $2.8 \%$ respectively and the precision is $0.5 \%, 0.2 \%, 0.4 \%, 0.7 \%, 1.9 \%, 0.3 \%, 0.4 \%, 0.5 \%$ and $0.8 \%$ respectively. Nearly $6 \%$ of the samples were analyzed in duplicates internal and external controls. The accuracy error and the precision error were estimated as $2.5 \%$ and $0.6 \%$ respectively, which denote high confidence in the results.

\subsection{Statistical Analysis Samples}

The statistical analysis was carried out using the SPSS v.23.0 software (Armonk, NY, USA). A descriptive analysis was obtained using the following variables: arithmetic mean, geometric mean, median, range, standard deviation, variable coefficient and kurtosis. In addition, several pollution indices were calculated to determine the level of contamination of heavy metals in the soil. Finally, a multivariate analysis was conducted using the principal components method to identify relationships between the heavy metal concentrations in the soil and to obtain information concerning the possible sources responsible for the presence of the heavy metals [42].

The GIS analysis (ArcGis v10.4), with the extensions of spatial analysis tools and geostatistical analysts, calculated the degree of spatial variability of each of the heavy metals and the pollution indices (the "improved" Nemerow Pollution Index and the Potential of Ecologic Risk Index), using standard Kriging to determine interpolation and the subsequent semivariogram analysis [43]. Kriging is an advanced geostatistical method that generates a surface area, based on a set of dispersed values. It can also generate an interactive study of the spatial characteristics, which is soil pollution caused by the presence of heavy metals in this case. In contrast to the deterministic interpolation methods of IDW 
and Spline, which directly depend on the surrounding measured values that determine the size of the resulting surface area, the geostatistical method Kriging is based on statistical models that include autocorrection. In essence, this is the statistical relationship between the points measured. The primary difference between Kriging and IDW (Inverse Distance Weight) is that IDW is the interpolation method that only takes distance dependency between soil samples into account. In comparison, Kriging is the most enhanced interpolation method that takes not only distance dependency, but also directional dependency into account. In the assessment of contaminated soil, this statistical geographic method generates a predicted surface area of the distribution of the heavy metals with certainty and predictive accuracy. A map of the predicted surface area was built using an equation (Equation (1)) that reveals the rules of dependency between points and then predicts the spatial or geographic distribution.

$$
Z\left(S_{0}\right)=\sum_{i=1}^{N} \lambda_{i} Z\left(S_{i}\right)
$$

where $Z\left(s_{i}\right)$ is the value measured in location $i ; \lambda_{i}$ is an unknown weighting of the measured value in location $i ; s_{0}$ is the location of the prediction; and $N$ is the number of measured values.

The two steps of the process carried out in this work are as follows: to create the variograms and the covariance functions to calculate the values dependent on statistics (spatial autocorrection) that are dependent on the model of autocorrection (adequacy of fit) and to determine unknown values (prediction). In this work, the Kriging method applied was standard, which presumes that the distance or the direction between sampling sites reflect a spatial correlation that can be used to explain variations within the surface area. The semivariogram model uses the spherical mathematical model, which adjusts the mathematical function to 12 sitepoints in a search radius variable [44].

\section{Results}

\subsection{Concentration of Heavy Metals in Soil}

The mean values of the heavy metals obtained as a result of the statistical analysis of the soil of the Northern Plateau of Spain can be seen in Table 2. These average values are similar to those described for other countries $[45,46]$.

Table 2. Statistical analysis of heavy metals in soil of the Northern Plateau of Spain.

\begin{tabular}{cccccccccc}
\hline & As & $\mathbf{C d}$ & $\mathbf{C o}$ & $\mathbf{C u}$ & $\mathbf{C r}$ & $\mathbf{H g}$ & $\mathbf{N i}$ & $\mathbf{P b}$ & $\mathbf{Z n}$ \\
\hline Mean $(\bar{x})$ & 6.71 & 0.08 & 6.49 & 17.19 & 18.68 & 0.08 & 12.05 & 14.10 & 35.31 \\
Geometric mean (GM) & 5.78 & 0.07 & 5.67 & 14.00 & 14.75 & 0.07 & 10.24 & 10.92 & 31.65 \\
Median (Me) & 6.50 & 0.06 & 6.15 & 14.55 & 15.60 & 0.07 & 11.01 & 9.96 & 34.50 \\
Minimum (min) & 1.80 & 0.04 & 1.30 & 1.00 & 1.74 & 0.01 & 2.11 & 2.25 & 4.16 \\
Maximum (max) & 15.70 & 0.38 & 17.84 & 48.90 & 51.50 & 0.45 & 37.20 & 73.04 & 71.45 \\
Standard deviation (S) & 3.51 & 0.06 & 3.21 & 10.69 & 12.28 & 0.06 & 6.76 & 11.32 & 14.63 \\
Coefficient of variation (CV) & 0.52 & 0.69 & 0.49 & 0.62 & 0.66 & 0.76 & 0.56 & 0.80 & 0.41 \\
Kurtosis & -0.31 & 11.27 & 0.23 & 0.86 & -0.15 & 18.30 & 1.48 & 6.75 & -0.52 \\
Natural geological Background & 5.67 & 0.07 & 4.18 & 11.20 & 12.53 & 0.05 & 8.63 & 9.39 & 21.17 \\
World mean & 20 & 0.40 & 8 & 12 & 50 & 0.10 & 25 & 15 & 40 \\
World ranks & $0.1-50$ & $0.01-2$ & $0.5-0.65$ & $1-200$ & $2-1500$ & $0.01-0.5$ & $2-500$ & $2-200$ & $1-800$ \\
\hline
\end{tabular}

The mean values of $\mathrm{As}, \mathrm{Cd}, \mathrm{Ni}, \mathrm{Cr}, \mathrm{Pb}, \mathrm{Cu}, \mathrm{Hg}, \mathrm{Co}$ and $\mathrm{Zn}$ in the soil were 1.18, 1.19, 1.40, 1.49, $1.50,1.54,1.55$ and 1.67 times higher, respectively, than their natural geological background levels. All these data show that there is an evident tendency towards the accumulation of heavy metals in the soil of the region studied.

The variation coefficient of $\mathrm{Pb}$ and $\mathrm{Hg}$, which were 0.80 and 0.76 respectively, were the highest, implying that these two metals had the greater variability throughout the area studied compared to the other metals also present in the soil: $\mathrm{As}, \mathrm{Cd}, \mathrm{Co}, \mathrm{Cu}, \mathrm{Cr}, \mathrm{Ni}, \mathrm{Pb}$ and $\mathrm{Zn}(0.52,0.78,0.49,0.62,0.66$, $0.76,0.56$ and 0.41$)$, which also showed high values (>41\%) dispersed along the sampled areas. 


\subsection{Assessment of the Environmental Risks: Contamination}

The Pollution factor $\left(P_{i}\right)$ quantifies the pollution of one individual metal, $P_{i}=C_{i} / B_{i}$, where " $C_{i}$ " is the concentration of the measured contaminant and " $B_{i}$ " is the geological background level, which allows the levels of the different metals to be determined.

The Nemerow index $\left(I_{N}\right)$ assesses soil quality, according to the degree of pollution of various metals and taking into account the pollution factor. This was defined by the following equation (Equation (2)):

$$
I_{N}=\sqrt{\left(P_{i_{\max }}{ }^{2}+P_{i_{a v e}}{ }^{2}\right)}
$$

where " $P i_{\max }$ " is the maximum value and " $P i_{a v e}$ " is the mean value of the pollution factors of all the metals (Table 3).

Table 3. Pollution factor and Nemerow index of the heavy metals.

\begin{tabular}{|c|c|c|c|c|c|c|c|c|c|c|c|c|}
\hline & $\begin{array}{c}P i=\mathrm{C} / \mathrm{B} \\
\text { As }\end{array}$ & $\begin{array}{c}P i=\mathrm{C} / \mathrm{B} \\
\mathrm{Cd}\end{array}$ & $\begin{array}{c}P i=\mathrm{C} / \mathrm{B} \\
\text { Co }\end{array}$ & $\begin{array}{c}P i=\mathrm{C} / \mathrm{B} \\
\mathrm{Cu}\end{array}$ & $\begin{array}{c}P i=\mathrm{C} / \mathrm{B} \\
\mathrm{Cr}\end{array}$ & $\begin{array}{c}P i=\mathrm{C} / \mathrm{B} \\
\mathrm{Hg}\end{array}$ & $\begin{array}{c}P i=\mathrm{C} / \mathrm{B} \\
\mathrm{Ni}\end{array}$ & $\begin{array}{c}P i=\mathrm{C} / \mathrm{B} \\
\mathrm{Pb}\end{array}$ & $\begin{array}{c}P i=\mathrm{C} / \mathrm{B} \\
\mathrm{Zn}\end{array}$ & $P i_{\max }$ & $P i_{\text {ave }}$ & $\mathbf{I}_{\mathbf{N}}$ \\
\hline Mean $(\bar{x})$ & 1.18 & 1.16 & 1.55 & 1.54 & 1.49 & 1.54 & 1.40 & 1.50 & 1.67 & 2.75 & 1.45 & 2.20 \\
\hline Median (Me) & 1.15 & 0.86 & 1.47 & 1.30 & 1.25 & 1.30 & 1.28 & 1.06 & 1.63 & 2.52 & 1.35 & 2.06 \\
\hline Minimum (min) & 0.32 & 0.57 & 0.31 & 0.09 & 0.14 & 0.19 & 0.24 & 0.24 & 0.20 & 0.78 & 0.47 & 0.65 \\
\hline Maximum (max) & 2.77 & 5.43 & 4.27 & 4.37 & 4.11 & 8.41 & 4.31 & 7.78 & 3.38 & 8.41 & 2.98 & 6.26 \\
\hline $\begin{array}{c}\text { Standard } \\
\text { deviation (S) }\end{array}$ & 0.62 & 0.80 & 0.77 & 0.95 & 0.98 & 1.17 & 0.78 & 1.21 & 0.69 & 1.31 & 0.49 & 0.96 \\
\hline
\end{tabular}

According to the results of this pollution factor, four categories were established: $34 \%$ of the samples studied have low pollution $(P i<1), 59.15 \%$ have moderate pollution $(1 \leq P i<3), 5.65 \%$ have high pollution $(3 \leq P i<6)$ and $4.62 \%$ have very high pollution $(P i>6)$. This data show that a large percentage of the soil was polluted to a low to moderate degree and that only a small amount of soil was highly polluted.

The levels of pollution according to the Nemerow index in the study area show that the majority of the soil presented low to moderate contamination, while only a small percentage was non-contaminated or slightly contaminated. The soil considered as "contaminated" (Class III, $1 \leq I_{N}<2$ ) represented $46.15 \%$ of the samples analyzed, the soil "moderately contaminated" (Class IV, $2 \leq I_{N}<3$ ) represented $36.92 \%$ and the "highly contaminated" soil (Class V, $I_{N}>3$ ) represented $14.62 \%$. The slightly contaminated soil (Class II, $0.7 \leq I_{N}<1$ ) were less represented and only made up $0.77 \%$ of the samples. In comparison, non-contaminated or clean soil (Class I, $I_{N}<0.7$ ) made up $1.54 \%$ of the samples analyzed.

The geo-accumulation index (Igeo) is calculated using the following equation (Equation (3)):

$$
I_{\text {geo }}=\log _{2}\left(\frac{C_{i}}{1.5 B_{i}}\right)
$$

where " $C_{i}$ " is the concentration measured of metal " $i$ " examined in the soil and " $\mathrm{B}$ " is the geological background level of metal " $i$ ". The factor 1.5 was used to correct possible variations in the background values of the specific metal in the environment. The resulting values were then classified as non-contaminated (Igeo $\leq 0$, Class 0 ), from non-contaminated to moderately contaminated $(0<$ Igeo $\leq 1$, Class 1$)$, moderately contaminated $(1<$ Igeo $\leq 2$, Class 2$)$, from moderately contaminated to highly contaminated $(2<$ Igeo $\leq 3$, Class 3$)$, highly contaminated $(3<$ Igeo $\leq 4$, Class 4$)$, from highly contaminated to extremely contaminated $(4<$ Igeo $\leq 5$, Class 5$)$ and extremely contaminated (Igeo $>5$, Class 6).

The geo-accumulation indices (Igeo) of the heavy metals studied allowed the pollution index, with only one factor to be analyzed in order to assess the presence of each specific metal and the corresponding level of contamination in the area studied. Furthermore, the "improved", multifactorial 
Nemerow index $\left(I_{M N}\right)$ showed the overall degree of pollution caused by the simultaneous presence of the nine heavy metals (Table 4 ).

Table 4. Geo-accumulation index $\left(\mathrm{I}_{\mathrm{geo}}\right)$ of the heavy metals.

\begin{tabular}{|c|c|c|c|c|c|c|c|c|c|c|c|c|}
\hline & \multicolumn{9}{|c|}{ Igeo } & \multirow{2}{*}{ Igeo $_{\text {ave }}$} & \multirow{2}{*}{ Igeo $_{\max }$} & \multirow{2}{*}{$\mathbf{I}_{\mathrm{NM}}$} \\
\hline & As & $\mathrm{Cd}$ & Co & $\mathrm{Cu}$ & $\mathrm{Cr}$ & $\mathrm{Hg}$ & $\mathrm{Ni}$ & $\mathbf{P b}$ & $\mathrm{Zn}$ & & & \\
\hline Mean $(\bar{x})$ & -0.50 & -0.34 & -0.02 & -0.30 & -0.31 & 0.16 & -0.23 & -0.05 & -0.05 & 0.18 & 0.91 & 0.79 \\
\hline Median (Me) & -0.33 & -0.58 & 0.10 & -0.24 & -0.23 & 0.15 & -0.13 & -0.19 & 0.07 & -0.18 & 0.90 & 0.72 \\
\hline Minimum (min) & -2.18 & -1.17 & -2.14 & -4.10 & -3.39 & -2.66 & -2.51 & -2.33 & -2.98 & 1.82 & -0.85 & 0.26 \\
\hline Maximum (max) & 0.94 & 2.08 & 1.64 & 1.51 & 1.50 & 2.85 & 1.63 & 2.69 & 1.12 & 0.77 & 2.85 & 2.07 \\
\hline Standard deviation (S) & 0.82 & 0.67 & 0.79 & 0.99 & 1.05 & 0.81 & 0.87 & 1.02 & 0.75 & 0.49 & 0.65 & 0.37 \\
\hline
\end{tabular}

After considering the geo-accumulation index, it was observed that the levels of heavy metal contamination of the soil in the superficial horizons of the Northern Plateau did not include Classes 4, 5 and 6 (from strongly polluted to extremely polluted). The majority of the soil contents were situated within Classes 0 (56.23\% of samples), 1 (36.07\%), 2 (7.79\%) and $3(2.34 \%)$ (unpolluted to moderately polluted).

The "improved" Nemerow index $\left(I_{M N}\right)$ substitutes the contamination factor $\left(P_{i}=C_{i} / B_{i}\right)$ for the equation Igeo $=\log _{2}\left(C_{i} / 1.5 B_{i}\right)$, in which the $I_{M N}$ is calculated using the following equation (Equation (4)):

$$
\left.I_{M N}=\sqrt{\frac{1}{2}\left(I_{\text {geo }}{ }^{2}+I_{\text {geo }}{ }^{2}\right.}{ }^{2}\right)
$$

where "Igeomax" is the maximum value of the Igeo of all metals in a sample and "Igeoave" is the arithmetic mean of the Igeo. After taking the Nemerow index into account, the soil contents within the study area ranged from contaminated to highly contaminated. However, using the "improved" Nemerow index $\left(I_{M N}\right)$, the soil was shown to be moderately to heavily contaminated. Specifically, $21.54 \%$ of the soil was uncontaminated ( $I_{M N}<0.5$, Class 0$), 54.61 \%$ was between uncontaminated to moderately contaminated $\left(0.5 \leq I_{M N}<1\right.$, Class 1$), 22.31 \%$ was moderately contaminated $\left(1 \leq I_{M N}<2\right.$, Class 2$)$ and $1.54 \%$ was moderately to heavily contaminated $\left(2 \leq I_{M N}<3\right.$, Class 3$)$. Furthermore, there are no samples belonging to Class 4 , which is heavily contaminated $\left(3 \leq I_{M N}<4\right)$; Class 5 , which is heavily to extremely contaminated $\left(4 \leq I_{M N}<5\right)$; and Class 6 , which is extremely contaminated $\left(I_{M N}>5\right)$.

The Potential of Ecological Risk Index $(E r)$ assesses the toxicity of some trace elements in sediments [47] and is currently widely applied in the analysis of soil [48-51]. Soil contaminated by heavy metals can cause serious risk to the environment and to human health owing to diverse interactions (agriculture, cattle breeding, etc.), which ultimately allow highly toxic heavy metals to enter into the food chain. The excessive accumulation of heavy metals in soil used for agricultural purposes can affect the quality and safety of food. Furthermore, this can increase the risk of serious diseases (cancer, kidney and liver damage, etc.) as well as causing environmental impact by combining environmental chemistry with biological and ecological toxicology [52].

To calculate the Potential of Ecological Risk index (Er) for each metal, the following equation was used (Equation (5)):

$$
E r_{m}=\operatorname{Tr}_{m} \cdot P_{i_{m}}
$$

where " $\mathrm{Tr}$ " is the toxicity coefficient of each metal, which standard values are: $\mathrm{Hg}=40, \mathrm{Cd}=30$, $\mathrm{As}=10, \mathrm{Co}=5, \mathrm{Cu}=5, \mathrm{Ni}=5, \mathrm{~Pb}=5, \mathrm{Cr}=2$ and $\mathrm{Zn}=1$.

The toxicity response index of all of the heavy metals studied was calculated using the following equation (Equation (6)):

$$
R I=\sum_{i=1}^{n} E r
$$

The Potential of Ecological Risk (RI) reflects the general situation of the contamination caused by the simultaneous presence of the nine heavy metals (Table 5). 
Table 5. Individual (Er) and potential (RI) Ecological Risk Index of the soil studied.

\begin{tabular}{ccccccccccc}
\hline & $E r$ As & $E r$ Cd & $E r$ Co & $E r$ Cu & Er Cr & Er Hg & Er Ni & Er Pb & Er Zn & $R \boldsymbol{I}$ \\
\hline Mean $(\bar{x})$ & 11.84 & 34.65 & 7.76 & 7.62 & 2.98 & 61.77 & 6.88 & 7.51 & 1.64 & 140.30 \\
Median & 11.46 & 25.71 & 7.36 & 6.49 & 2.49 & 51.85 & 6.31 & 5.30 & 1.62 & 134.45 \\
Minimum (min) & 3.17 & 17.14 & 1.56 & 0.45 & 0.28 & 7.41 & 1.22 & 1.20 & 0.20 & 3.17 \\
Maximum (max) & 27.69 & 162.86 & 21.34 & 21.83 & 8.22 & 336.30 & 21.55 & 38.89 & 3.38 & 486.70 \\
Standard deviation (S) & 6.18 & 24.08 & 3.83 & 4.80 & 1.96 & 46.79 & 3.98 & 6.03 & 0.72 & 57.83 \\
\hline
\end{tabular}

The categories established for the RI index for classifying risk are: low ecological risk of potential contamination $(R I<150)$, moderate ecological risk $150 \leq R I<300)$, considerable ecological risk $(300 \leq R I<600)$ and very high ecological risk $(R I>600)$. It was observed in the area studied that a large percentage of the soil samples $(96.92 \%)$ were within low to moderate ecological risk of potential contamination, with only a small proportion $(3.08 \%)$ posing a considerable risk of potential contamination.

\subsection{Analysis of Principal Components}

Using a data matrix comprised of the concentrations obtained for each heavy metal in each sample site analyzed, a principal component analysis was conducted in order to reduce the dimensionality of the study. A three-component solution was chosen to best explain $70.285 \%$ of the variance (Table 6).

The first principal component accounted for $42.838 \%$ of the variance found within the data matrix (Table 6), which was mainly caused by $\mathrm{Cu}, \mathrm{Cr}, \mathrm{Ni}, \mathrm{Co}$ and $\mathrm{Zn}$ concentrations, with very high charges $(0.942,0.928,0.927,0.773$ and 0.681 , respectively), as shown in Table 7 . As previously mentioned, the mean values of all elements in the sampled soil were slightly higher than the values of the natural geological background levels. This indicated that the first component collected all the information from the samples, which had heavy metal contents that originated mainly from the parent rock [53].

Table 6. Cumulative variance and variance of the major components.

\begin{tabular}{cccc}
\hline \multirow{2}{*}{ Component } & \multicolumn{3}{c}{ Initial Eigenvalues } \\
\cline { 2 - 4 } & Total & \% Variance & \% Accumulated \\
\hline $\mathbf{1}$ & 3.855 & 42.838 & 42.838 \\
$\mathbf{2}$ & 1.498 & 16.643 & 59.481 \\
$\mathbf{3}$ & 0.972 & 10.805 & 70.285 \\
$\mathbf{4}$ & 0.858 & 9.533 & 79.818 \\
$\mathbf{5}$ & 0.789 & 8.762 & 88.580 \\
$\mathbf{6}$ & 0.596 & 6.623 & 95.204 \\
$\mathbf{7}$ & 0.265 & 2.945 & 98.149 \\
$\mathbf{8}$ & 0.098 & 1.087 & 99.236 \\
$\mathbf{9}$ & 0.069 & 0.764 & 100.000 \\
\hline
\end{tabular}

Table 7. Matrix for the principal component analysis of heavy metals.

\begin{tabular}{cccc}
\hline \multirow{2}{*}{ Component } & \multicolumn{3}{c}{ Components } \\
\cline { 2 - 4 } & $\mathbf{1}$ & $\mathbf{2}$ & $\mathbf{3}$ \\
\hline Copper & 0.942 & -0.116 & 0.063 \\
Chrome & 0.928 & -0.092 & 0.021 \\
Nickel & 0.927 & 0.062 & 0.025 \\
Cobalt & 0.773 & 0.445 & 0.017 \\
Zinc & 0.681 & 0.078 & 0.099 \\
Lead & 0.394 & -0.310 & -0.215 \\
Arsenic & -0.036 & 0.780 & -0.385 \\
Mercury & 0.094 & -0.666 & 0.110 \\
Cadmium & -0.141 & 0.346 & 0.867 \\
\hline
\end{tabular}


The second principal component accounted for $16.643 \%$ of the variance, with arsenic and mercury having the highest and inverse charge factors ( 0.780 and -0.666 respectively, Figure 2 left). The inverse sign in the changes in factors should be interpreted together with the geographical localization analysis of the samples. The general meaning is that the two metals appear in the area studied in inversely proportional concentrations. For a specific soil sample with a high concentration of As, the concentration of $\mathrm{Hg}$ is small in general and vice versa. As the average values of these metals were proportionally higher than the geological background levels ( $\mathrm{As}=52 \%$ and $\mathrm{Hg}=76 \%$ ), this information combined with the geographical localization analysis of the samples indicated that the second component collected information from the sites where the presence of these elements could be determined not only from the parent rock (the lithogenic factor) but also by industrial practices.

The third principal component accounted for $10.805 \%$ of the overall information. In this, Cd had the highest load factor as it is 0.867 higher than the rest of the other metals. Within the areas sampled, the mean value of this element exceeded the natural geological background level, having a high value for the coefficient of variation $\left(\mathrm{CV}_{\mathrm{Cd}}=78 \%\right)$. The geographical location of the samples with the highest $\mathrm{Cd}$ values showed that the second component basically collected information of samples where the concentration of this element was caused by agricultural practices (and thus, being influenced by the lithological factor) (Figure 2 right).
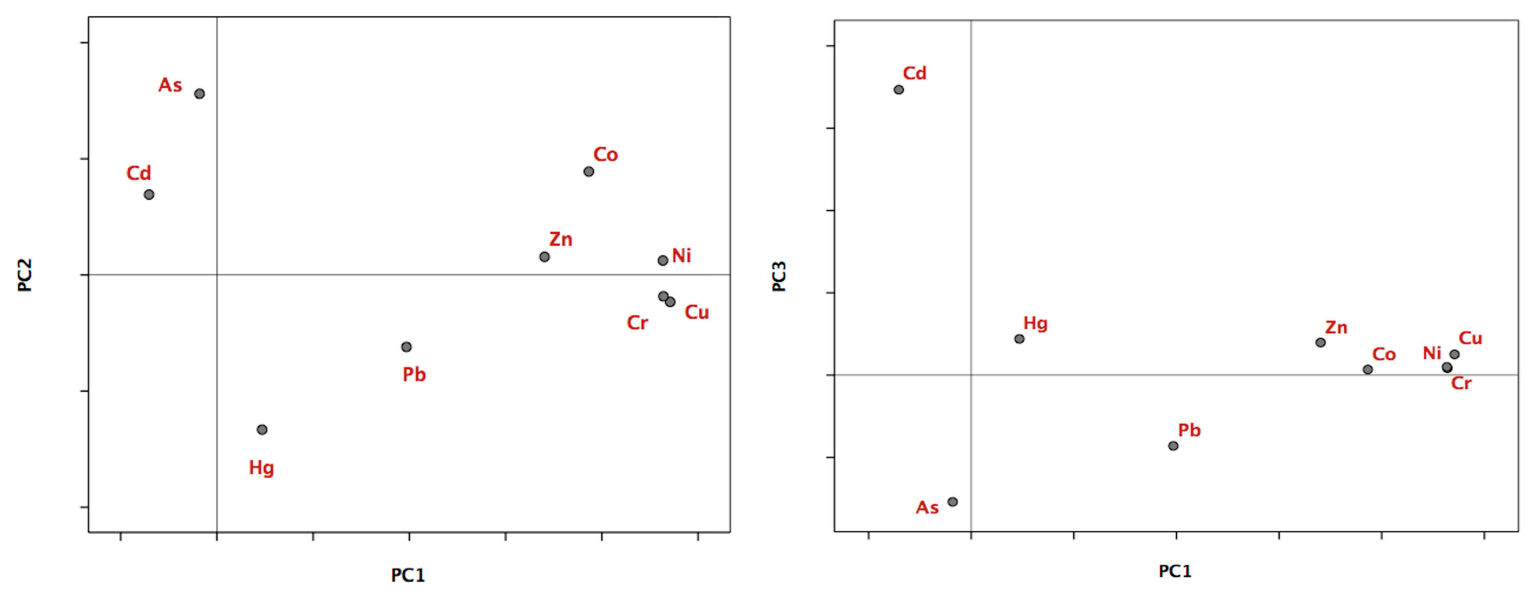

Figure 2. Representation of the heavy metals, in the factorial planes 1-2 (left) and 1-3 (right).

Lead $(\mathrm{Pb})$ contributed very little to the three principal components of this multivariate solution. It was known that the mean value of this element in the study area exceeded the natural geological background level and that its coefficient of variation was the highest out of all the metals studied $\left(\mathrm{CV}_{\mathrm{Pb}}=80 \%\right)$. This indicated that the distribution of $\mathrm{Pb}$ was diverse and fluctuating, with its concentration at each site potentially being conditioned by multiple factors, including human activities [54] and the parent rock. This might account for the results as within the factorial solution, $\mathrm{Pb}$ was the only element studied that showed low charge factors within the three principal components $(0.394,-0.310$ and -0.215 , respectively), which determined its position within the factorial planes (Figure 2).

The Pearson correlation coefficients for the heavy metal concentrations in the soil samples (Table 8) showed a direct relationship between the majority of the metal concentrations from samples (if we exclude $\mathrm{Cd}$ as well as $\mathrm{As}$ and $\mathrm{Hg}$ in some cases, which had negative correlation values indicating an inverse relationship). These statistically significant levels, marked with asterisks (** $p$-value $<0.01$; * $p$-value $<0.05)$, showed that the relationship between the metal concentrations were sometimes small but not negligible. 
Table 8. Pearson correlation matrix for the heavy metal concentrations in the soil samples.

\begin{tabular}{|c|c|c|c|c|c|c|c|c|c|}
\hline & As & $C d$ & Co & $C u$ & $\mathrm{Cr}$ & $H g$ & $\mathrm{Ni}$ & $\mathrm{Pb}$ & $\mathrm{Zn}$ \\
\hline As & 1 & 0.100 & 0.260 * & $-0.235 *$ & -0.145 & $-0.252 *$ & -0.075 & -0.148 & -0.020 \\
\hline$C d$ & 0.100 & 1 & -0.040 & -0.182 & -0.178 & -0.111 & -0.156 & -0.117 & -0.048 \\
\hline Co & $0.260 *$ & -0.040 & 1 & $0.629^{* *}$ & $0.620 * *$ & -0.050 & $0.758^{* *}$ & 0.129 & $0.504^{* *}$ \\
\hline$C u$ & $-0.235^{*}$ & -0.182 & $0.629^{* *}$ & 1 & $0.897^{* *}$ & 0.080 & $0.894^{* *}$ & $0.364^{* *}$ & $0.586^{* *}$ \\
\hline $\mathrm{Cr}$ & -0.145 & -0.178 & $0.620^{* *}$ & $0.897^{* *}$ & 1 & 0.088 & $0.863^{* *}$ & $0.381^{* *}$ & 0.559 ** \\
\hline $\mathrm{Hg}$ & $-0.252 *$ & -0.111 & -0.050 & 0.080 & 0.088 & 1 & 0.010 & 0.094 & 0.055 \\
\hline $\mathrm{Ni}$ & -0.075 & -0.156 & $0.758^{* *}$ & $0.894^{* *}$ & $0.863^{* *}$ & 0.010 & 1 & $0.300^{* *}$ & 0.478 ** \\
\hline $\mathrm{Pb}$ & -0.148 & -0.117 & 0.129 & $0.364^{* *}$ & $0.381^{* *}$ & 0.094 & $0.300 * *$ & 1 & 0.196 \\
\hline $\mathrm{Zn}$ & -0.020 & -0.048 & $0.504^{* *}$ & $0.586^{* *}$ & $0.559 * *$ & 0.055 & $0.478^{* *}$ & 0.196 & 1 \\
\hline
\end{tabular}

$\mathrm{Cu}, \mathrm{Cr}, \mathrm{Ni}$ and $\mathrm{Zn}$ were the most related elements with direct connections, which indicated that these metals were generally present in the samples at the same time and in equivalent or proportional quantities, suggesting that the origin of these elements was mainly lithological. However, there was an inverse relationship between the concentrations of $\mathrm{Cd}$ and As with the rest of the metals. The metals, $\mathrm{Hg}$ and $\mathrm{Cd}$, had a sporadic inverse relationship with $\mathrm{Co}$. These relationships could serve to identify artificial sources caused by different human activities.

\subsection{Correlation between Heavy Metal Concentrations and Soil Properties}

The correlation analysis between the total contents of heavy metals and some soil properties has shown (Table 9) that the clay content and the cation exchange capacity are highly correlated with the concentration of $\mathrm{Co}, \mathrm{Cu}, \mathrm{Cr}, \mathrm{Ni}, \mathrm{Pb}$ and $\mathrm{Zn}$. This result confirmed the high affinity of specific elements with the clay minerals within the soil. However, the soil $\mathrm{pH}$ only showed a statistically significant relationship with the $\mathrm{Pb}$ concentration, while the percentage of the organic matter was found to only significantly change in proportion to the concentration of $\mathrm{Cd}$.

Table 9. Coefficient of correlation of the concentrations of trace elements with the properties of the soils $(* *, * * *$ level of significance being $p<0.01$ and $p<0.001$, respectively).

\begin{tabular}{ccccc}
\hline Element & pH & \% Organic Matter & \% Clay & CEC \\
\hline As & 0.23 & 0.12 & 0.01 & 0.09 \\
Cd & 0.25 & $0.59^{* * *}$ & 0.18 & 0.08 \\
Co & 0.23 & 0.04 & $0.63^{* * *}$ & $0.79^{* * *}$ \\
$\mathbf{C u}$ & 0.30 & 0.06 & $0.76^{* * *}$ & $0.88^{* * *}$ \\
$\mathbf{C r}$ & 0.32 & 0.12 & $0.84^{* * *}$ & $0.93^{* * *}$ \\
$\mathbf{H g}$ & $0.17^{* *}$ & 0.12 & $0.05^{* * *}$ & 0.1 \\
$\mathbf{N i}$ & 0.26 & 0.01 & $0.72^{* * *}$ & $0.85^{* * *}$ \\
$\mathbf{P b}$ & $0.51^{* *}$ & 0.12 & $0.50^{* *}$ & $0.52^{* *}$ \\
$\mathbf{Z n}$ & 0.32 & 0.16 & $0.77^{* * *}$ & $0.89^{* * *}$ \\
\hline
\end{tabular}

\subsection{Spatial Distribution of Heavy Metal Content in Soil}

The geostatistical method of spatial interpolation (standard Kriging) allowed for the spatial distribution of the values of each metal in non-sampled sites (Figure 3) to be predicted using the values obtained from the samples collected in the field. It was shown that the closest values were more similar than those that were further apart. 

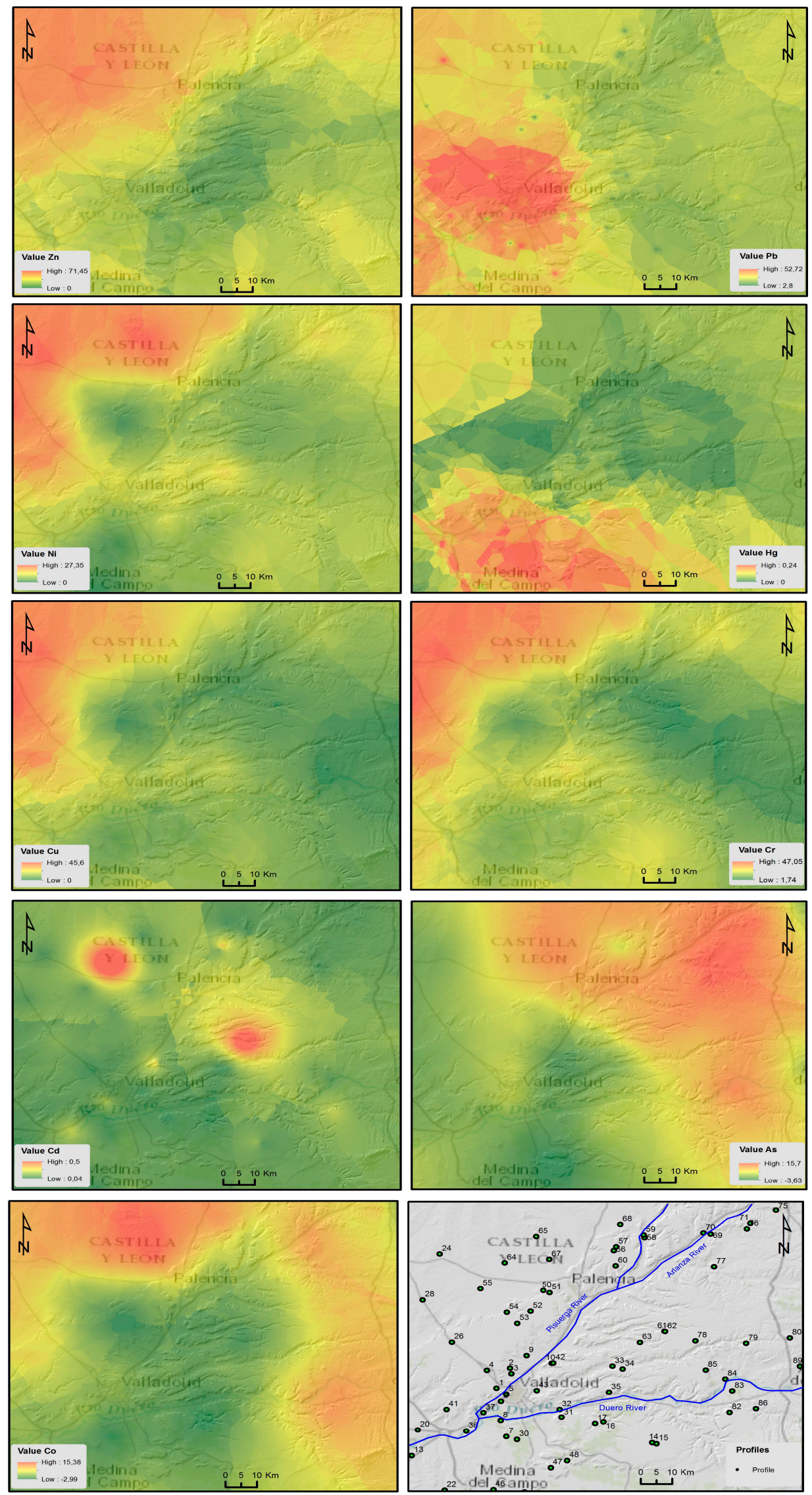

Figure 3. Spatial distribution of the content of the different heavy metals in the soil of the study area. 
By applying the geostatistical analysis extension, we analyzed the resulting charge histogram of all the sample data and implemented the logarithmic transformation. This allowed the frequency histogram to be fitted to a normal distribution and equalized the values of the mean and median. Standard Kriging was applied with a prediction surface output and a logarithmic transformation. This process was further carried out by applying an exponential-type Kernel function and obtaining a spherical semivariogram (Figure 4A) with real anisotropy. Following this, a standard neighborhood operation (Neighborhood type) was performed with maximum neighbors of five and minimum neighbors of two samples (Figure 4B). The standard error prediction map (Figure 4C) showed maximum values between the range of $0.48-0.57$ when compared with the interpolation map.

The cartography of the risk of soil contamination from the $\mathrm{I}_{\mathrm{NM}}$ (Figure $5 \mathrm{~A}$ ) showed that the highest concentrations of heavy metals were located in the north-western section of the area studied (in the city outskirts of Villalón de Campos), in soil developed on top of the sediments of the "Tierra de Campos" Facies as well as in soil situated in the center and south-eastern areas (in the surroundings of the cities of Valladolid). Uncontaminated or slightly contaminated soil was present in the eastern section of the region.

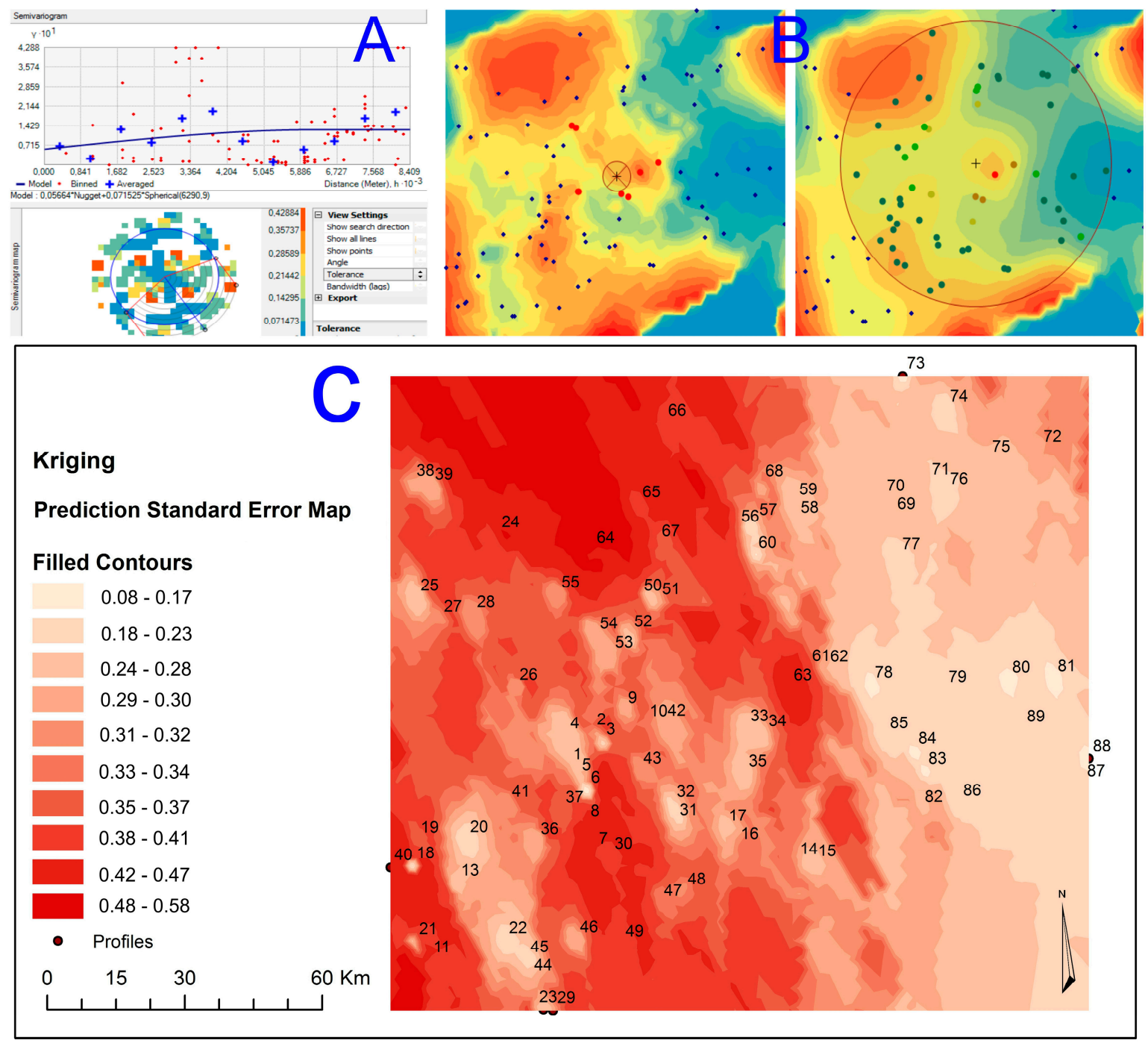

Figure 4. Spherical semivariogram obtained using: (A) exponential-type Kernel function, (B) Neighborhood Interpolation and (C) Error prediction map. 

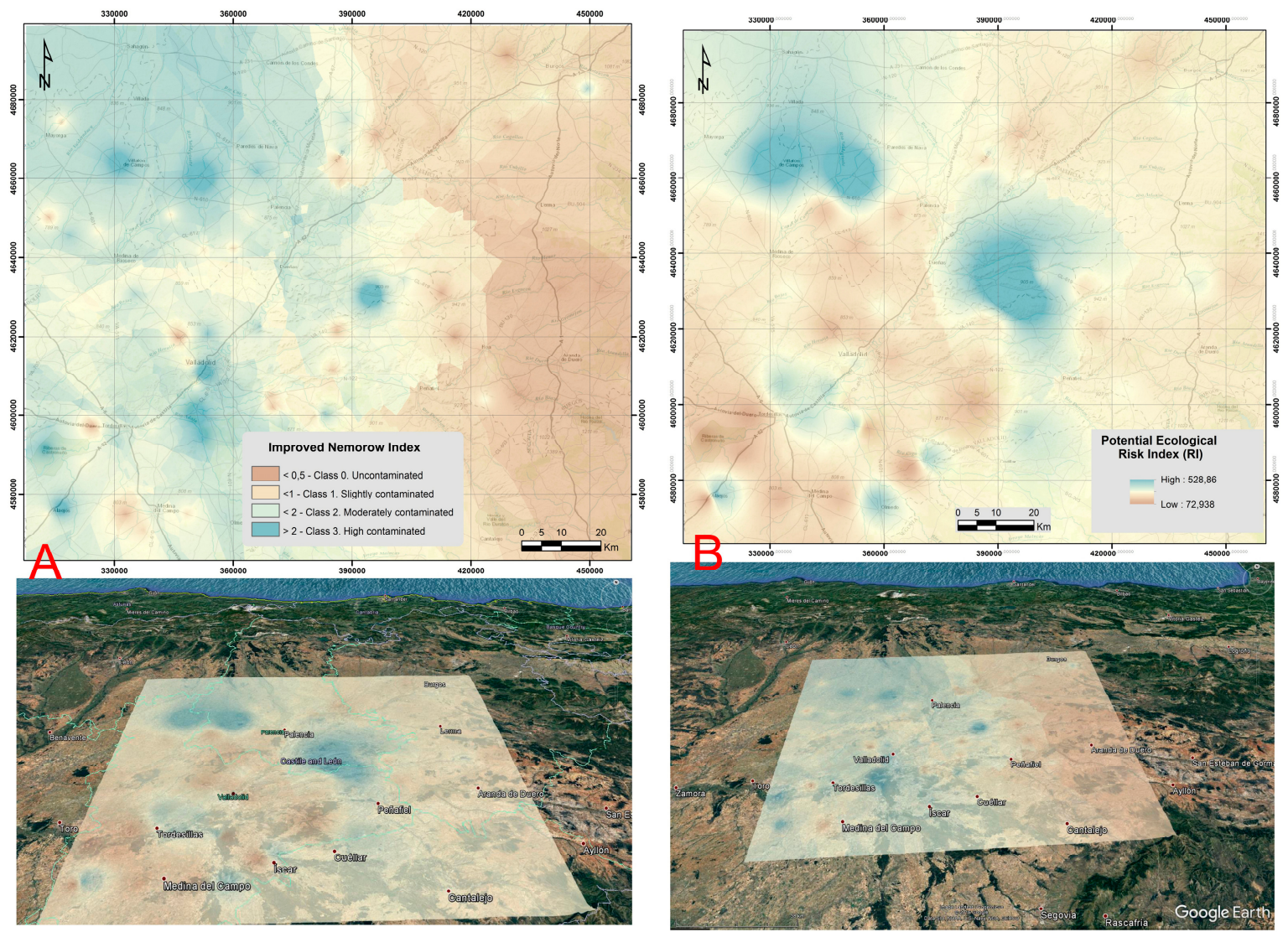

Figure 5. Global heavy metal pollution index measured by: (A) Improved Nemerow Index and (B) Potential Ecological Risk Index on top of the free 3D virtual globe (Google Earth).

If we consider the spatial distribution of the Potential Ecological Risk Index (RI) (Figure 5B), it can be observed that the highest levels of contamination by heavy metals were concentrated in the central area (to the east of the town of Dueñas) and north-west of the area studied (in the outskirts of Villalón de Campos), in soil developed on top of the sediments of the "Tierra de Campos" Facies as well as on Miocene limestones and loams. Other areas with moderate potential ecological risk indices were found on the city outskirts of Olmedo and Alaejos as well as between Tordesillas and Valladolid.

\section{Discussion}

The evaluation of the environmental risk of heavy metals in the soil has been carried out through several pollution indices, a principal components analysis and the spatial distribution of nine heavy metals.

The indexes of Nemerow (IN), Pollution Factor (Pi), Geoaccumulation Index (Igeo), Nemerow "Improved" Index (IMN) and Individual Ecological Risk (Er) and Potential Indices (IR) have been calculated.

After taking the Nemerow index into account, the soil within the study area ranged from being contaminated to highly contaminated. However, using the "improved" Nemerow index $\left(I_{M N}\right)$, the soil was shown to be moderately to heavily contaminated. A large difference was observed when calculating the percentage and degree of contamination of the soil using each of the different contamination indices. In the soil of the Northern Plateau of Spain, the $I_{M N}$ was a better representation of the actual degree of contamination present. 
The calculations based on the Potential Ecological Risk Index indicate that the majority of soil samples $(96.92 \%)$ have a low to moderate ecological risk of potential contamination, while the minority $(3.08 \%)$ of the soil has a considerable risk of contamination.

Therefore, both the "improved" Nemerow index and the Potential Ecological Hazard Index are the best in informing us of the degree of contamination in the surface horizons of the soil of the Northern Plateau of Spain.

The nine trace elements have been divided into three main components: $\mathrm{CP} 1(\mathrm{Cu}, \mathrm{Cr}, \mathrm{Ni}, \mathrm{Co}$ and $\mathrm{Zn}$ ); $\mathrm{CP} 2$ (As and $\mathrm{Hg}$ ) and $\mathrm{CP} 3(\mathrm{Cd})$. Pb has a similar and scarce contribution across all the three main components. Pearson correlation coefficients and their significance levels indicate that most concentrations of heavy metals are positively correlated with each other (with the exception of $\mathrm{Cd}$ correlations). Furthermore, these were all statistically significant correlations, which implies that the contents of these heavy metals have been supplied from very similar sources of contamination. The correlation coefficients of the metals belonging to the $\mathrm{CP} 1$ (between $\mathrm{Cr}$ and $\mathrm{Cu} ; \mathrm{Ni}$ and $\mathrm{Cu} ; \mathrm{Cr}$ and $\mathrm{Ni}$ as well as $\mathrm{Ni}$ and $\mathrm{Co})$ indicate a strong and significant linear correlation $(p<0.01)$, providing evidence for one shared origin of these metals. The lack of significant linear correlation between $\mathrm{Cd}$ and other metals suggests that sources of $\mathrm{Cd}$ must be very different from those of other metals. These data suggest that concentrations of heavy metals could be affected by more than one source of pollution, including the following: from the parent rock itself, from agricultural activities and from the discharge of wastewater into rivers and streams. It is hypothesized that the contamination is caused by industrial development and increasing population density (Figure 6).

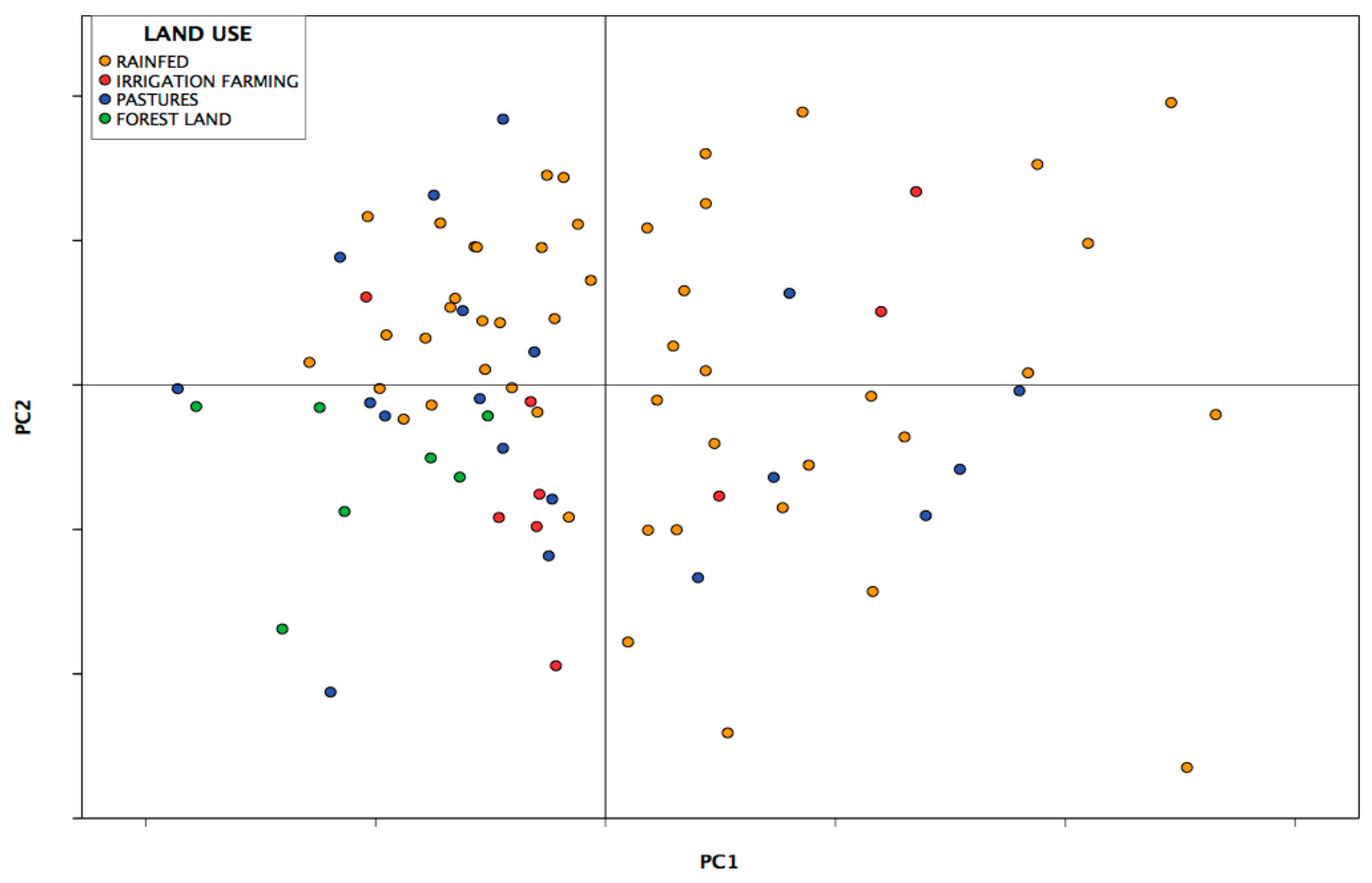

Figure 6. Representation of the sampling points in the factorial plane 1-2 according to land use.

A number of soil parameters, such as organic matter content, $\mathrm{pH}$, clay content and cation exchange capacity, have been measured to determine their influence on or correlation with the content of heavy metals. By conducting the correlation analysis, the clay content and cation exchange capacity (CEC) were found to be significantly correlated with $\mathrm{Co}, \mathrm{Cu}, \mathrm{Cr}, \mathrm{Ni}, \mathrm{Pb}$ and $\mathrm{Zn}$ concentrations. This confirms the high affinity of certain elements with the minerals of the soil clay. However, soil $\mathrm{pH}$ is significantly correlated only with $\mathrm{Pb}$ concentration. It was found that the concentration of the heavy metals increases in the more clay-like horizons of the soil (Bt horizons of the Alfisols and Bw of the Inceptisols), which 
can easily be explained if we take into account that the adsorption capacity of these elements in soil depends on a number of properties, such as clay content, organic matter and cation exchange capacity.

A mapping, of the spatial distributions of heavy metal contents in the soil of the Northern Plateau (Spain) has been carried out using by interpolation methods (Kriging).

The distribution of the heavy metals $(\mathrm{Ni}, \mathrm{Cu}, \mathrm{Cr}$, and $\mathrm{Zn})$ was very similar and all had high concentrations in the soil. These heavy metals were found in the north-western section of the study area in soil that had developed on top of the sediments of the "Tierra de Campos" facies. High values for these elements were also observed in the soil overlaying Miocene limestones as well as on top of the terraces, alluvial deposits of the rivers and streams that run through the area. The concentrations of these metals were influenced by the contents of the parent rock. Furthermore, the concentrations of $\mathrm{Cu}$ and $\mathrm{Zn}$ could have been influenced by agricultural practices (fertilized with waste, fertilizers and chemical pesticides). The highest $\mathrm{Pb}$ content was found within the surroundings of Valladolid, the most populated and industrial city [55], in soil on top of terraces as well as alluvial deposits of rivers and on top of the clay-like sandstones of the "Tierra de Campos" Facies. Lead in the soil came mainly from vehicle exhaust emissions, industrial sources and the run-off of residual waters into rivers and streams. The content of $\mathrm{Hg}$ was dispersed throughout the entire study area with most of the content found in the south-western section of the region on top of the terraces of the River Duero. This element might have a natural (parent rock) and anthropogenic origin (atmospheric residues coming from the incineration of waste products). The distribution of Co decreased in a concentric manner from the periphery towards the south-eastern section of the study area, with the highest amount of content located in the developed soil overlaying sediments of the "Tierra de Campos" Facies (provinces of Palencia and Burgos). Co in the soil came mainly from the parent rock. With regards to Cd, its content was distributed as two concentric circles, with one situated toward the north-eastern part of Valladolid in soil that had developed on top of limestone wastelands and chalky loams (Cuestas Facies). The other circle contained the highest concentration of $\mathrm{Cd}$ in the region, which was measured in the soil taken from an area surrounding the electric transformer-accumulator of Fuentes de Nava (Palencia). It is worth noting that $\mathrm{Cd}$ is used in nickel-cadmium accumulators. The highest concentrations of As were situated in the north-eastern corner of the study area in soil that had developed over the terraces and alluvial deposits of the rivers Pisuerga, Arlanza, Arlanzón, Carrión, and Riaza in the provinces of Palencia and Burgos. The origin of As may have been lithogenic as well as also being due to the application of manure, fertilizers and pesticides.

The overall analysis of the soil contamination in the study area was carried out using two contamination indices: the improved Nemerow index $\left(\mathrm{I}_{\mathrm{NM}}\right)$ and the potential ecological risk index (RI). Both reflect the general situation of the contamination caused by the simultaneous presence of the nine heavy metals. This was useful for evaluating the possible sources of the heavy metals in the area studied and for identifying the soil that contained the highest concentrations of the metals.

\section{Conclusions}

The correlation analysis between the total contents of heavy metals and some soil properties has shown that the clay content and the cation exchange capacity are highly correlated with the concentrations of $\mathrm{Co}, \mathrm{Cu}, \mathrm{Cr}, \mathrm{Ni}, \mathrm{Pb}$ and $\mathrm{Zn}$.

According to the multivariate statistics, the metals from the soil of the region studied are related with three principal components. Of these, the first one is closely related to $\mathrm{Cu}, \mathrm{Cr}, \mathrm{Ni}, \mathrm{Co}$ and $\mathrm{Zn}$. The second principal component has a strong relationship with $\mathrm{As}$ and $\mathrm{Hg}$, while the third is explained primarily by $\mathrm{Cd}$. According to its origin and dominant substrates, lead has a similar contribution and is scarcely represented within the three main components in the multivariate solution.

On the basis of the Pearson correlation coefficients and the levels of significance for the contents of heavy metals in the soil samples, it can be deduced that most of the levels are positively correlated with each other (except with the correlations of $\mathrm{Cd}$ ). In addition, the correlations are statistically significant, 
which implies that the contents of these metals have originated from similar sources of pollution and could be affected by more than one source of contamination.

Taking into account the values obtained from heavy metals, analysis of main components and their spatial distribution, it can be concluded that a determinant of concentrations of most metals in the soil of the Northern Plateau of Spain is the nature of the mother rock. Some metals, such as $\mathrm{Cu}, \mathrm{Zn}$ and As, have also increased their content in soil due to certain agricultural activities (fertilizers and chemical pesticides). $\mathrm{Hg}$ is related to soil that has developed on alluvial deposits and irrigated soil. The soil that has developed on limestones and calcareous sediments has a high $\mathrm{Cd}$ content and the greater concentration (anomaly) of $\mathrm{Cd}$ in the region occurs in the vicinity of an electric transformer of an urban nucleus. The highest concentration of $\mathrm{Pb}$ occurs in the vicinity of Valladolid due to the gases from the vehicles, industrial sources as well as the discharge of waste water to rivers and streams. In accordance with the improved Nemerow index, most of the soil of the Northern Plateau of Spain are considered to be between "between non-contaminated to moderately contaminated". According to the Potential Ecological Risk Index, the soil presents a general level of risk that varies from "low to moderate".

The results of this study demonstrate that agricultural production can continue, but there should be some improvement measures to protect the security of agricultural products. This might include a reduction in the amount of fertilizers and pesticides used as well as the application of treatments to the soil in some places. In addition, the results obtained in this research should be useful for establishing future land planning guidelines or for providing recommendations for land use within this region.

Supplementary Materials: The following are available online at www.mdpi.com/1660-4601/14/6/568/s1, Nemerow Index Kmz, RI Index Kmz and HTML File-Stadistical Kriging.

Acknowledgments: This work has been supported by the USAL research projects CGL2012-37281-C02.01, CGL2015-67169-P and CGL2015-69919-R (MINECO-FEDER).

Author Contributions: Fernando Santos-Francés, Antonio Martínez-Graña, and Carmelo Ávila Zarza performed the geostatistic analysis. Carmelo Ávila zarza performed the multivariate analysis. Pilar Alonso Rojo, Fernando Santos-Francés, and Antonio García Sánchez brought the soil samples, and assisted in analyzing heavy metal concentration as well as in field sampling. Fernando Santos-Francés and Antonio Martínez-Graña participated in the design of the sample map with ArcGis. All the authors revised the final version of the manuscript.

Conflicts of Interest: The authors declare no conflict of interest. The founding sponsors had no role in the design of the study; in the collection, analyses, or interpretation of data; in the writing of the manuscript; or in the decision to publish the results.

\section{References}

1. Yi, Y.J.; Wang, Z.Y.; Zhang, K.; Guoan, Y.U.; Duan, X. Sediment pollution and its effect on fish through food chain in the Yangtze River. Int. J. Sediment. Res. 2008, 23, 338-347. [CrossRef]

2. Zahra, A.; Hashmi, M.Z.; Malik, R.N.; Ahmed, Z. Enrichment and geo-accumulation of heavy metals and risk assessment of sediments of the Kurang Nallah-Feeding tributary of the Rawal Lake reservoir, Pakistan. Sci. Total Environ. 2014, 470-471, 925-933. [CrossRef] [PubMed]

3. Hiller, E.; Lachká, L.; Jurkovič, L.; Ďurža, O.; Fajč́ková, K.; Vozár, J. Occurrence and distribution of selected potentially toxic elements in soil of playing sites: A case study from Bratislava, the capital of Slovakia. Environ. Earth Sci. 2016, 75, 1390. [CrossRef]

4. Sapcanin, A.; Cakal, M.; Jacimovic, Z.; Pehlic, E.; Jancan, G. Soil pollution fingerprints of children playgrounds in Sarajevo city. Environ. Sci. Pollut. Res. 2016, 47, 21-26. [CrossRef]

5. Li, C.; Kang, S.; Wang, X.; Ajmone-Marsan, F.; Zhang, Q. Heavy metals and rare earth elements (REEs) in soil from the Nam Co Basin, Tibetan Plateau. Environ. Geol. 2008, 53, 1433-1440. [CrossRef]

6. Atapour, H. Geochemistry of potentially harmful elements in topsoils around Kerman city, southeastern Iran. Environ. Earth Sci. 2015, 74, 5605-5624. [CrossRef] 
7. Martínez-Graña, A.M.; Goy, J.L.; Zazo, C. Dominant soil map in "Las Batuecas-Sierra de Francia" and “Quilamas” nature parks (Central System, Salamanca, Spain). J. Maps 2015, 11, 371-379. [CrossRef]

8. Zhang, C.; Tang, Y.; Luo, L.; Xu, W. Outlier identification and visualization for Pb concentrations in urban soil and its implications for identification of potential contaminated land. Environ. Pollut. 2009, 157, 3083-3090. [CrossRef] [PubMed]

9. Li, F.; Huang, J.; Zeng, G.; Liu, W.; Huang, X.; Huang, B.; Gu, Y.; Shi, L.; He, X.; He, Y. Toxic metals in topsoil under different land uses from Xiandao District, middle China: Distribution, relationship with soil characteristics, and health risk assessment. Environ. Sci. Pollut. Res. 2015, 22, 12261-12275. [CrossRef] [PubMed]

10. Tembo, B.D.; Sichilongo, K.; Cernak, J. Distribution of copper, lead, cadmium and zinc concentrations in soil around Kabwe town in Zambia. Chemosphere 2006, 63, 497-501. [CrossRef] [PubMed]

11. Gu, Y.G.; Wang, Z.H.; Lu, S.H.; Jiang, S.J.; Mu, D.H.; Shu, Y.H. Multivariate statistical and GIS-based approach to identify source of anthropogenic impacts on metallic elements in sediments from the mid Guangdong coasts. China Environ. Pollut. 2011, 163, 248-255. [CrossRef] [PubMed]

12. Palumbo, B.; Angelone, M.; Bellanca, A. Influence of inheritance and pedogenesis on heavy metal distribution in soil of Sicily, Italy. Geoderma 2000, 95, 247-266. [CrossRef]

13. Salonen, V.; Korkka-Niemi, K. Influence of parent sediments on the concentration of heavy metals in urban and suburban soil in Turku, Finland. Appl. Geochem. 2007, 22, 906-918. [CrossRef]

14. Albanese, S.; Sadeghi, M.; Lima, A.; Cicchella, D.; Dinelli, E.; Valera, P.; Falconi, M.; Demetriades, A.; de Vivo, B.; GEMAS Project Team. GEMAS: Cobalt, $\mathrm{Cr}, \mathrm{Cu}$ and $\mathrm{Ni}$ distribution in agricultural and grazing land soil of Europe. J. Geochem. Explor. 2015, 154, 81-93. [CrossRef]

15. Nicholson, F.A.; Smith, S.R.; Alloway, B.J. An inventory of heavy metals inputs to agricultural soil in England and Wales. Sci. Total Environ. 2003, 311, 205-219. [CrossRef]

16. Nguyen, T.; Ozaki, A.; Nguyen, H.; Nguyen Duc, A.; Tran, Y.; Kurosawa, K. Arsenic and Heavy Metal Contamination in Soil under Different Land Use in an Estuary in Northern Vietnam. Int. J. Environ. Res. Public Health 2016, 13, 1091. [CrossRef] [PubMed]

17. Yu, L.; Cheng, J.; Zhan, J.; Jiang, A. Environmental quality and sources of heavy metals in the topsoil based on multivariate statistical analyses: A case study in Laiwu City, Shandong Province, China. Nat. Hazards 2016, 81, 1435-1445. [CrossRef]

18. Nagajyoti, P.C.; Lee, K.D.; Sreekanth, T.V.M. Heavy metals, occurrence and toxicity for plants: A review. Environ. Chem. Lett. 2010, 8, 199-216. [CrossRef]

19. Senesil, G.S.; Baldassarre, G.; Senesi, N.; Radina, B. Trace element inputs into soil by anthropogenic activities and implications for human health. Chemosphere 1999, 39, 343-377. [CrossRef]

20. Imperato, M.; Adamo, P.; Naimo, D.; Arienzo, M.; Stanzione, D.; Violante, P. Spatial distribution of heavy metals in urban soil of Naples city (Italy). Environ. Pollut. 2003, 124, 247-256. [CrossRef]

21. McGrath, D.; Zhang, C.; Carton, O.T. Geostatistical analyses and hazard assessment on soil lead in Silvermines area, Ireland. Environ. Pollut. 2004, 127, 239-248. [CrossRef] [PubMed]

22. Amini, M.; Afyuni, M.; Khademi, H.; Abbaspour, K.C.; Schulin, R. Mapping risk of cadmium and lead contamination to human health in soil of Central Iran. Sci. Total Environ. 2005, 347, 64-77. [CrossRef] [PubMed]

23. Burgos, P.; Madejón, E.; Pérez-de-mora, A.; Cabrera, F. Spatial variability of the chemical characteristics of a trace-element-contaminated soil before and after remediation. Geoderma 2006, 130, 157-175. [CrossRef]

24. Lee, C.S.L.; Li, X.; Shi, W.; Cheung, S.C.N.; Thornton, I. Metal contamination in urban, suburban, and country park soil of Hong Kong: A study based on GIS and multivariate statistics. Sci. Total Environ. 2006, 356, 45-61. [CrossRef] [PubMed]

25. Yaserebi, J.; Saffari, M.; Fathi, H.; Karimian, N.; Moazallahi, M.; Gazni, R. Evaluation and comparison of Ordinary Kriging and Inverse Distance Weighting methods for prediction of spatial variability of some soil chemical parameters. Res. J. Biol. Sci. 2009, 4, 93-102.

26. Kishné, A.S.; Bringmark, E.; Bringmark, L.; Alriksson, A. Comparison of ordinary and lognormal kriging on skewed data of total cadmium in forest soil of Sweden. Environ. Monit. Assess. 2003, 84, 243-263. [CrossRef] [PubMed]

27. Hu, K.L.; Zhang, F.R.; Li, H.; Huang, F.; Li, B.G. Spatial patterns of soil heavy metals in urban-rural transition zone of Beijing. Pedosphere 2006, 16, 690-698. [CrossRef] 
28. Lark, R.M. Towards soil geostatistic. Spat. Stat. 2012, 1, 92-99. [CrossRef]

29. Bai, J.; Xiao, R.; Cui, B.; Zhang, K.; Wang, Q.; Liu, X. Assessment of heavy metal pollution in wetland soil from the young and old reclaimed regions in the Pearl River Estuary, South China. Environ. Pollut. 2011, 159, 817-824. [CrossRef] [PubMed]

30. Yang, Z.; Lu, W.; Long, Y.; Bao, X.; Yang, Q. Assessment of heavy metals contamination in urban topsoil from Changchun City, China. J. Geochem. Explor. 2011, 108, 27-38. [CrossRef]

31. Lu, Y.; Jia, C.M.; Zhang, G.; Zhao, Y.; Wilson, M.A. Spatial distribution and source of potential toxic elements (PTEs) in urban soil of Guangzhou. China. Environ. Earth Sci. 2016, 75, 329. [CrossRef]

32. Goovaerts, P. Factorial kriging analysis: A useful tool for exploring the structure of multivariate spatial soil information. J. Soil Sci. 1992, 53, 597-619. [CrossRef]

33. Webster, R.; Atteia, O.; Dubois, J.P. Coregionalization of trace metals in the soil in the Swiss Jura. Eur. J. Soil Sci. 1994, 45, 205-218. [CrossRef]

34. Gurhan, Y.M.; Semiha, I. Multivariate analyses to determine the origin of potentially harmful heavy metals in beach and dune sediments from Kizkalesi coast, Turkey. Bull. Environ. Contam. Toxicol. 2008, 81, 57-68.

35. Olivera, M.A.; Websterb, R. A tutorial guide to geostatistics: Computing and modelling variograms and kriging. Catena 2014, 113, 56-69. [CrossRef]

36. Chen, T.B.; Wong, J.W.C.; Zhou, H.Y.; Wong, M.H. Assessment of trace metal distribution and contamination in surface soil of Hong Kong. Environ. Pollut. 1997, 96, 61-68. [CrossRef]

37. Junta de Castilla y León. Mapa Geológico y Minero de Castilla y León, Escala 1:400.000; SIEMCALSA: Valladolid, Spain, 1997.

38. Soil Conservation Service. Soil Survey Laboratory Methods and Procedure for Collecting Soil Samples; USDA: Washington, DC, USA, 1972.

39. Martínez-Graña, A.M.; Goy, J.L.; Zazo, C.; Silva, P.G. Soil map and 3D virtual tour using a database of soil-forming factors. Environ. Earth Sci. 2016, 75, 1-19. [CrossRef]

40. Santos-Francés, F.; Fernández, J.M.; Alonso, P. Estudio de la Distribución de Suelos y sus Procesos de Erosión en Valladolid, Utilizando Imágenes de Satélite Landsat-5 (tm). En "Teledetección: Usos y Aplicaciones"; Universidad de Valladolid: Valladolid, Spain, 1997; pp. 187-194.

41. United States Department of Agriculture. Soil Survey Laboratory Methods Manual; United States Department of Agriculture: Lincoln, NE, USA, 2004.

42. Facchinelli, A.; Sacchi, E.; Mallen, L. Multivariate statistical and GIS-based approach to identify heavy metal sources in soil. Environ. Pollut. 2001, 114, 313-324. [CrossRef]

43. Trangmar, B.B.; Yost, R.S.; Uehara, G. Application of geostatistics to spatial studies of soil properties. Adv. Agron. 1985, 38, 45-93.

44. ESRI. Creating, Editing and Managing Geodatabases for ArcGIS Desktop; Virtual Campus, ESRI Educational Service, Environmental Systems Research Institute, Inc.: Redlands, CA, USA, 2014.

45. Kabata-Pendias, A.; Pendias, H. Trace Elements in Soil and Plants, 3nd ed.; CRC Press: Boca Raton, FL, USA, 2001; p. 413.

46. Berrow, M.L.; Reaves, G.A. Background levels of trace elements in soil. In Proceedings of the International Conference on Environmental Contamination, London, UK, 18-21 July 1984; CEP Consultants: Edimburgh, UK, 1984.; pp. 330-340.

47. Zheng, G.Z. Evaluation of heavy metal contamination and its potential ecological risk to the farmland soil in Loess Hilly Area of North Shaanxi Province. Chin. J. Soil Sci. 2013, 44, 1491-1495.

48. Mermut, A.R.; Jain, J.C.; Song, L.; Kerrich, R.; Kozak, L.; Jana, S. Trace elements concentrations of selected soilsand fertilizers in Saskatchewan, Canada. J. Environ. Qual. 1996, 25, 845-853. [CrossRef]

49. Saeedi, M.; Li, L.Y.; Salmanzadeh, M. Heavy metals and polycyclic aromatic hydrocarbons: Pollution and ecological risk assessment in street dust of Tehran. J. Hazard. Mater. 2012, 227-228, 9-17. [CrossRef] [PubMed]

50. Li, F.; Huang, J.H.; Zeng, G.M.; Yuan, X.Z.; Li, X.D.; Liang, J.; Wang, X.Y.; Tang, X.J.; Bai, B. Spatial risk assessment and sources identification of heavy metals in surface sediments from the Dongting Lake, Middle China. J. Geochem. Explor. 2013, 132, 75-83. [CrossRef]

51. Liang, J.; Liu, J.Y.; Yuan, X.Z.; Zeng, G.M.; Lai, X.; Li, X.D.; Wu, H.P.; Yuan, Y.J.; Li, F. Spatial and temporal variation of heavy metal risk and source in sediments of Dongting Lake wetland, mid-south China. J. Environ. Sci. Health 2015, 50, 100-108. [CrossRef] [PubMed] 
52. Suresh, G.; Sutharsan, P.; Ramasamy, V.; Venkatachalapathy, R. Assessment of spatial distribution and potential ecological risk of the heavy metals in relation to granulometric contents of Veeranam lake sediments, India. Ecotoxicol. Environ. Saf. 2012, 84, 117-124. [CrossRef] [PubMed]

53. Lu, J.S.; Zhang, Z.L.; Liu, Y.; Dai, J.; Wang, X. Sources identification and hazardous risk delineation of heavy metals contamination in Rizhao City. Acta Geogr. Sin. 2012, 67, 971-984.

54. Zhao, Y.F.; Guo, H.L.; Sun, Z.Y.; Shi, X.Z.; Wu, K.N. Principle component analyses based on soil knowledge as a tool to indicate origin of heavy metals in soil. Sci. Geogr. Sin. 2013, 28, 45-50.

55. Guan, Y.; Shao, C.; Ju, M. Heavy metal contamination assessment and partition for industrial and mining gathering areas. Int. J. Environ. Res. Public Health 2014, 11, 7286-7303. [CrossRef] [PubMed]

2017 by the authors. Licensee MDPI, Basel, Switzerland. This article is an open access article distributed under the terms and conditions of the Creative Commons Attribution (CC BY) license (http://creativecommons.org/licenses/by/4.0/). 